Brazilian Journal
of Chemical
Engineering

ISSN 0104-6632

Printed in Brazil

www.abeq.org.br/bjche

Vol. 28, No. 04, pp. 605 - 616, October - December, 2011

\title{
HETEROGENEOUS FENTON PROCESS USING THE MINERAL HEMATITE FOR THE DISCOLOURATION OF A REACTIVE DYE SOLUTION
}

\author{
F. V. F. Araujo ${ }^{1 *}$, L. Yokoyama ${ }^{1}$, L. A. C. Teixeira ${ }^{2}$ and J. C. Campos ${ }^{1}$ \\ ${ }^{1}$ School of Chemistry, Federal University of Rio de Janeiro, Fax: + (55) (21) 2562-7596, Rio de Janeiro - RJ, Brazil. \\ E-mail: fabiana@eq.ufrj.br \\ ${ }^{2}$ Catholic University of Rio de Janeiro and Peróxidos do Brasil (Solvay Group), Rio de Janeiro - RJ, Brazil.
}

(Submitted: March 29, 2011 ; Revised: July 18, 2011 ; Accepted: July 18, 2011)

\begin{abstract}
This work reports a study on the heterogeneous Fenton reaction using hematite powder $\left(\mathrm{Fe}_{2} \mathrm{O}_{3}\right)$ in suspension for the discolouration of the reactive dye Drimarene Red X-6BN in aqueous solutions. The efficiency of the process was studied as a function of the experimental conditions: initial $\mathrm{pH} ; \mathrm{H}_{2} \mathrm{O}_{2}$ dose; and hematite powder concentration; all of which showed a strong effect on the reaction kinetics. Under the best experimental conditions: $\mathrm{pH}=2.5 ; \mathrm{H}_{2} \mathrm{O}_{2}$ dose $=800 \mathrm{mg} / \mathrm{L}$; and [Hematite] $=20 \mathrm{~g} / \mathrm{L}$, it was possible to remove about $99 \%$ of the initial colour in 120 minutes in a batch reaction at $25^{\circ} \mathrm{C}$. The analysis of the kinetic results suggests that the reaction is initiated by heterogeneous generation of free radicals on the hematite surface, but as soluble iron (III) and iron (II) species are released into the solution during the course of the reaction, a simultaneous homogeneous Fenton reaction step propagates and contributes to the overall reaction.
\end{abstract}

Keywords: Heterogeneous Fenton reaction; Hematite; Reactive dye.

\section{INTRODUCTION}

Reactive dyes are a major class of coloured organic compounds commonly used as dyestuffs in textiles. Most of these dyes contain the azo group $(-\mathrm{N}=\mathrm{N}-)$ in their structure, which is responsible for the colour applied on the fibre. Until recently, no really effective physical-chemical or biological methods existed for removing the colour produced by residual dyes in wastewaters (Arslan et al., 2000). Alternative routes to the conventional treatments have been reported, including Advanced Oxidative Processes such as $\mathrm{H}_{2} \mathrm{O}_{2} / \mathrm{UV}, \mathrm{O}_{3} / \mathrm{UV}$ and Fenton reagent (Georgiou et al., 2002; Neamtu et al., 2002; Swaminathan et al., 2003). The Fenton process has so far been the preferred process used in the treatment of this kind of industrial effluent because it is a cost effective source of hydroxyl radicals ( $\left.{ }^{\circ} \mathrm{OH}\right)$ and easy to operate (Lin and Lo, 1997; Kang et al., 2002; Kin et al., 2004). The degradation of organic pollutants by the $\mathrm{Fe}^{3+} / \mathrm{H}_{2} \mathrm{O}_{2}$ system is much slower than that achieved by the $\mathrm{Fe}^{2+} / \mathrm{H}_{2} \mathrm{O}_{2}$ system, due to the lower reactivity of $\mathrm{Fe}^{3+}$ with $\mathrm{H}_{2} \mathrm{O}_{2}$ (Pignatello, 1992). However, to our knowledge, despite its high efficiency, the adoption of the Fenton process in actual industrial operations is still not considered to be the ultimate treatment process due to the need of conducting the operation at low $\mathrm{pH}$ and the amount of sludge generated in the neutralization / coagulation step.

The homogeneous Fenton process is usually conducted at $\mathrm{pH} 3$ to maintain the iron species in

*To whom correspondence should be addressed 
solution and requires a down-stream treatment to raise the $\mathrm{pH}$ and precipitate and settle the catalyst as ferric hydroxide. This separation is not simple due to the colloidal characteristics of the resulting dispersion (Plata et al., 2010).

More recently, research has been oriented toward the immobilization of iron compounds on different supports or the use of insoluble iron oxides (goethite, magnetite and hematite) in order to facilitate iron separation, employing mainly solid supports to avoid more complex post-treatments (Khan and Watts, 1992; Lin and Gurol, 1998; Valentine and Wang, 1998; Herrera et al., 2001). This process has been referred to as the heterogeneous Fenton reaction and employs a variety of iron immobilization techniques (Pham et al., 2009) or makes use of a mass of aggregated iron such as different iron oxides, which are separated at the end of the reaction. From the point of view of an industrial application, a heterogeneous Fenton process is conceptually attractive because it should not require the sludge separation step typical of the conventional homogeneous process (Dantas et al., 2006).

Kwan and Voelker (2003) concluded that the heterogeneous Fenton reaction occurs at the mineral catalyst surface and reported that the rate of production or formation of hydroxyl radicals depends on the hydrogen peroxide concentration and the surface area of the iron oxide. In another approach, other investigators (Chou and Huang, 1999; Teel et al., 2001; Lu et al., 2002) have suggested that the mechanism of the heterogeneous Fenton reaction only starts on the surface and then continues mainly in the bulk of the aqueous solution with participation of dissolved iron species, just like in the conventional homogeneous Fenton reaction.

The objective of the present work was to investigate the efficiency of naturally-occurring hematite $\left(\mathrm{Fe}_{2} \mathrm{O}_{3}\right)$ as an iron-containing solid catalyst for use in Fenton processes directed to the discolouration of effluents of textile industries. This chosen catalyst is particularly attractive because: (1) it is an abundant low-cost mineral; and (2) when it loses its surface activity and the time comes for replacement, it can be discarded in blast furnaces as feed material for pig-iron production without causing environmental impact. Drimarene Red, which is one of the various azo dyes used in the textile industry, was chosen as the target dye for the present study due to its high resistance to degradation and its relevance as a type of compound typical of those found in difficult-to-treat effluents of textile industries.

\section{MATERIALS AND METHODS}

\section{Materials}

A sample of the reactive dye Drimarene Red X-6BN (C.I. Reactive Red 243) was supplied by Clariant. Distilled water was used to prepare the $100 \mathrm{mg} / \mathrm{L}$ dye solution. Hydrogen peroxide $(50 \% \mathrm{w} / \mathrm{w})$ was provided by Peróxidos do Brasil (Solvay Group). The hematite mineral used in this work was a ground sample obtained from Vale (mining company); it was used without any purification. It had a BET surface area of $0.85 \mathrm{~m}^{2} / \mathrm{g}$ and a mean particle size of $0.064 \mathrm{~mm}$; its characterization is presented in Tables 1 and 2. Other reagent grade chemicals used in this study were supplied by Vetec $\left(\mathrm{FeSO}_{4} .7 \mathrm{H}_{2} \mathrm{O}, \mathrm{H}_{2} \mathrm{SO}_{4}\right.$ and $\left.\mathrm{NaOH}\right)$.

\section{Table 1: Chemical Composition of the hematite sample}

\begin{tabular}{|c|c|}
\hline Component & $\mathbf{( \% )}$ \\
\hline $\mathrm{Fe}$ & 63 \\
$\mathrm{SiO}_{2}$ & 8.55 \\
$\mathrm{P}$ & 0.01 \\
$\mathrm{Al}_{2} \mathrm{O}_{3}$ & 0.42 \\
$\mathrm{TiO}_{2}$ & 0.02 \\
$\mathrm{CaO}$ & 0.01 \\
$\mathrm{Mn}$ & 0.28 \\
$\mathrm{MgO}$ & 0.03 \\
\hline
\end{tabular}

Table 2: Physical properties of the hematite sample

\begin{tabular}{|l|r|}
\hline BET Area $\left(\mathbf{m}^{2} / \mathbf{g}\right)$ & \multicolumn{1}{|c|}{$\mathbf{0 . 8 5}$} \\
\hline Particle Size $(\mathrm{mm})$ & $0.075-0.064$ \\
Volume of micropores $\left(\mathrm{cm}^{3} / \mathrm{g}\right)$ & 0.0028 \\
Area of micropores $\left(\mathrm{m}^{2} / \mathrm{g}\right)$ & 0.22 \\
Average pore diameter $(\mathrm{A})$ & 97.5 \\
\hline
\end{tabular}

\section{Kinetic Experiments}

The effects of the relevant variables, $\mathrm{pH}, \mathrm{H}_{2} \mathrm{O}_{2}$ dose, and $\mathrm{Fe}_{2} \mathrm{O}_{3}$ suspension concentration, were investigated over ranges compatible with a potential industrial application. The influence of a possible simultaneous conventional homogeneous Fenton reaction occurring in the solution phase was also evaluated, especially the possible influence of the chain reaction initiated by the soluble $\mathrm{Fe}^{3+}$ in the degradation of the chosen dye. The oxidation experiments were carried out as batch runs in a stirred $600 \mathrm{~mL}$ open cylindrical Pyrex reactor, with $500 \mathrm{~mL}$ of dye solution with a concentration 100 $\mathrm{mg} / \mathrm{L}$ and a predetermined amount of suspended hematite powder at room temperature $\left(25 \pm 1^{\circ} \mathrm{C}\right)$. The reactions were initiated by adding a calculated 
shot of $50 \% \mathrm{H}_{2} \mathrm{O}_{2}$ solution to the $\mathrm{pH}$-adjusted dye hematite aqueous suspension. Samples were withdrawn at predetermined time intervals, filtered through a $0.45 \mu \mathrm{m}$ cellulose ester membrane, and analyzed for absorbance, residual hydrogen peroxide and dissolved iron concentrations. The rate of discolouration of the dye solution was studied at different $\mathrm{pH}$ values and dosages of hematite and hydrogen peroxide. Additional sets of experiments were carried out to check for the possibility of a contribution from a homogeneous Fenton reaction, caused by the dissolution of iron from the hematite catalyst. In these trials, the same dye solution used in the discolouration experiments was kept in contact with the same hematite catalyst powder for 2 hours. The solution was then filtered through a $0.45 \mu \mathrm{m}$ membrane and a calculated dose of $\mathrm{H}_{2} \mathrm{O}_{2}$ was added to the dye solution and left to react for 120 minutes. At the end of the reaction time, the $\mathrm{pH}$ was adjusted to $\mathrm{pH}=8$ and the solution was analyzed for residual $\mathrm{H}_{2} \mathrm{O}_{2}$, and its absorbance was measured.

\section{Analytical Methods}

Colour removal was measured using a Shimadzu UV-mini 1240 spectrophotometer. UV-VIS spectra were recorded at $516 \mathrm{~nm}$ where the maximum absorbance was obtained. Residual hydrogen peroxide was determined by a colorimetric method based on the generation of peroxovanadium formed by the reaction of hydrogen peroxide with ammonium metavanadate (Oliveira et al., 2001), with maximum absorption at $446 \mathrm{~nm}$. The COD determination was corrected for residual $\mathrm{H}_{2} \mathrm{O}_{2}$ accordingly. The presence of dissolved $\mathrm{Fe}$ was determined by colorimetry, by means of the reaction with ortho-phenanthroline (APHA, 2005) and confirmed by atomic absorption spectrometry (Shimadzu, model AA-7000).

\section{RESULTS AND DISCUSSION}

\section{Effects of Dosage of $\mathrm{H}_{2} \mathrm{O}_{2} ; \mathrm{Fe}_{2} \mathrm{O}_{3}$ Suspension Concentration; $\mathrm{pH}$; and Temperature}

Figure 1 shows the effect of adding different $\mathrm{H}_{2} \mathrm{O}_{2}$ doses on the discolouration of dye solutions at $\mathrm{pH}=3.5$ and [hematite powder] $=20 \mathrm{~g} / \mathrm{L}$.

No significant colour removal was observed without $\mathrm{H}_{2} \mathrm{O}_{2}$, indicating that dye adsorption on the solid does not contribute to significant colour removal, but this does not mean that dye molecules do not adsorb on the catalyst surface. As the $\mathrm{H}_{2} \mathrm{O}_{2}$ dose was increased up to $800 \mathrm{mg} / \mathrm{L}$, a corresponding gain in the discolouration rate was observed; this confirms the effect of free radical oxidation of the dye molecule, since $\mathrm{H}_{2} \mathrm{O}_{2}$ on its own is not sufficiently reactive for the oxidation of azo dyes.

The other significant parameter is the hematite suspension concentration; its effect on the discolouration rate at $\mathrm{pH}=3.5$ and dosage of $\mathrm{H}_{2} \mathrm{O}_{2}=800 \mathrm{mg} / \mathrm{L}$, is shown in Figure 2.

The increase of the hematite dosage increased the discolouration rate as a result of the correspondingly higher mineral surface area available for the reaction. This was also seen by Kwan and Voelker (2003), who observed that the organic matter decomposition rate is favoured by increasing the iron oxide concentration in a heterogeneous Fenton-like reaction. The increase in the concentration of the mineral suspension promoted the decomposition of the compounds, probably by increasing the available area and / or the amount of available iron (surface or aqueous) for the Fenton reaction, thus promoting the generation of hydroxyl radicals (Kong et al., 1998).

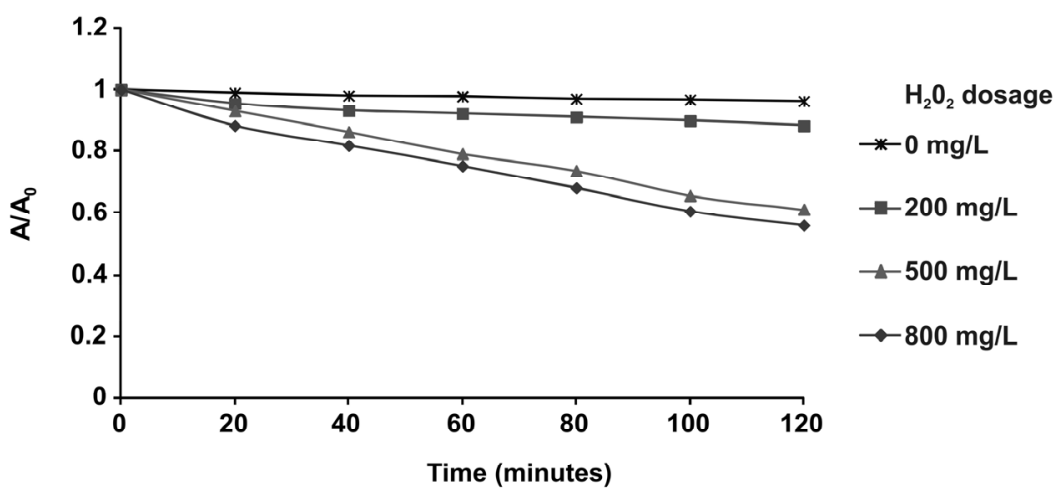

Figure 1: Effect of hydrogen peroxide dosage on the colour removal of the dye solution by heterogeneous Fenton oxidation. $\mathrm{A}=$ final absorbance, $\mathrm{A}_{0}=$ initial absorbance. Initial conditions: $[$ hematite $]=20 \mathrm{~g} / \mathrm{L} ;[$ dye $]=100 \mathrm{mg} / \mathrm{L} ; \mathrm{T}=25^{\circ} \mathrm{C} ; \mathrm{pH}=3.5$. 


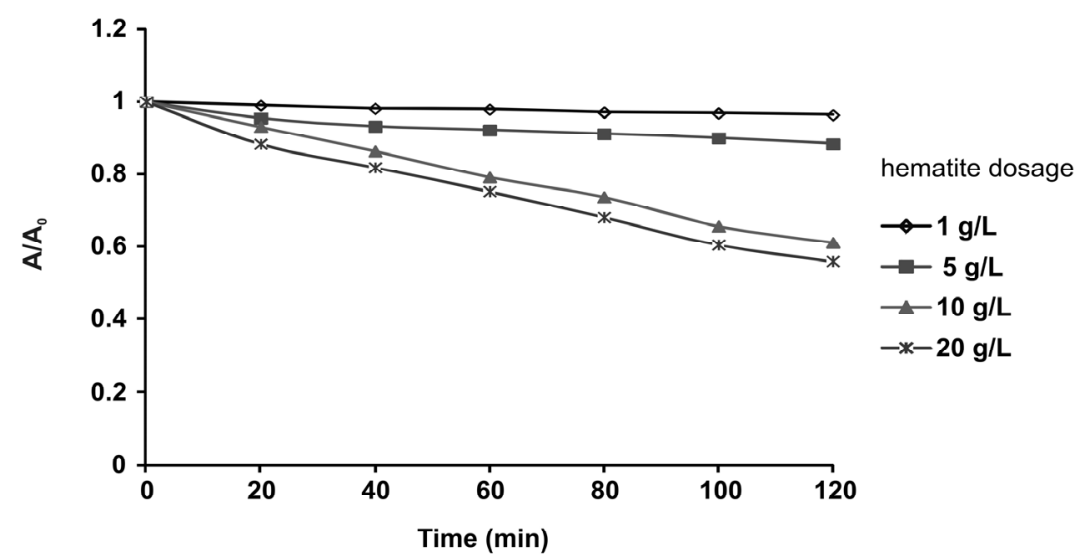

Figure 2: Effect of hematite dosage on the colour removal of the dye solution by heterogeneous Fenton oxidation. $\mathrm{A}=$ final absorbance, $\mathrm{A}_{0}=$ initial absorbance. Initial conditions: $\left[\mathrm{H}_{2} \mathrm{O}_{2}\right]=800 \mathrm{mg} / \mathrm{L} ;$ [dye $]=100 \mathrm{mg} / \mathrm{L} ; \mathrm{T}=25^{\circ} \mathrm{C}, \mathrm{pH}=3.5$.

The effect of $\mathrm{pH}$ on the decomposition of the dye by hydrogen peroxide and hematite was examined in runs with [hematite] $=20 \mathrm{~g} / \mathrm{L}$ and $\mathrm{H}_{2} \mathrm{O}_{2}$ dose $=800 \mathrm{mg} / \mathrm{L}$, as reported in Figure 3. No significant discolouration was obtained in experiments conducted at $\mathrm{pH}=5.5$, the natural $\mathrm{pH}$ of the dye solution.

Lowering the initial $\mathrm{pH}$ to $\mathrm{pH}=3.5$ led to a moderate improvement in the colour removal rate; after 120 minutes of reaction, about $50 \%$ discolouration was achieved. An even further significant improvement in the reaction rate was observed in the run conducted at $\mathrm{pH}=2.5$. This was also reported by Lu et al. (2002), who observed that the Fenton system with iron oxide is more effective at $\mathrm{pH}$ lower than 3.0.

Additional kinetic runs were performed in order to investigate the effect of temperature and to determine the apparent activation energy of the reaction (Figure 4).

Figure 4 shows the change in absorbance of the solution with temperature. Increasing temperature causes faster reduction in the absorbance with reaction time. When the temperature was varied from 25 to $55^{\circ} \mathrm{C}$, there was a significant reduction in the absorbance of the solution within the first hour of reaction.

From the kinetic data at different temperatures it was possible to determine the initial rates of reaction and then calculate the apparent activation energy by applying the Arrhenius equation. These results are described in Table 3. The calculated apparent activation energy of the reaction at $\mathrm{pH}=2.5$ was found to be $10.6 \mathrm{kcal} / \mathrm{mol}$. This, according to Levenspiel (1962), indicates that the non-elementary reaction studied is controlled by a chemical reaction step.

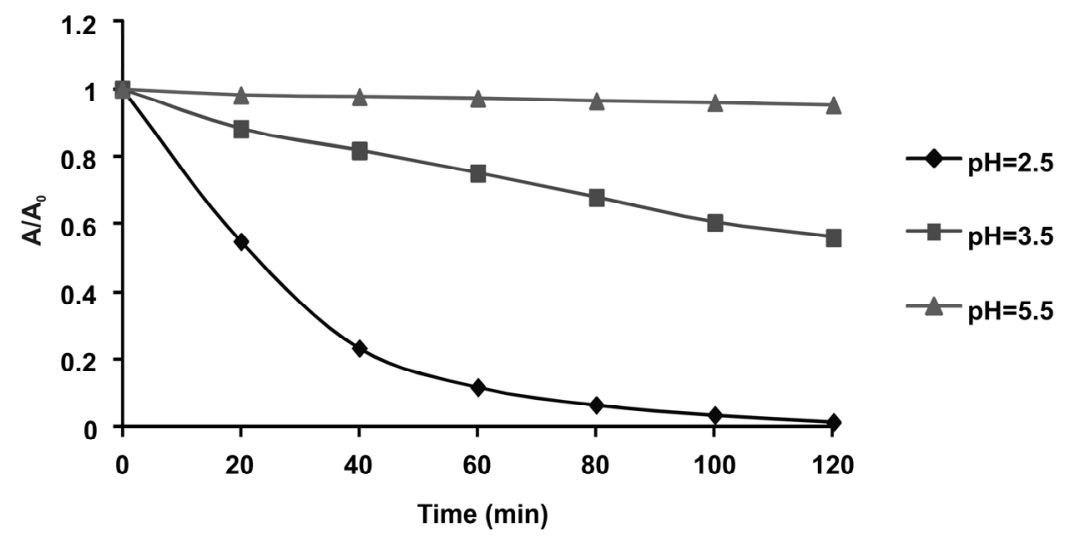

Figure 3: Effect of $\mathrm{pH}$ on the colour removal of the dye solution by heterogeneous Fenton oxidation. $\mathrm{A}=$ final absorbance, $\mathrm{A}_{0}=$ initial absorbance. Initial conditions: $[$ hematite $]=20 \mathrm{~g} / \mathrm{L} ;\left[\mathrm{H}_{2} \mathrm{O}_{2}\right]=800 \mathrm{mg} / \mathrm{L},[$ dye $]=100 \mathrm{mg} / \mathrm{L} ; \mathrm{T}=25^{\circ} \mathrm{C}$. 


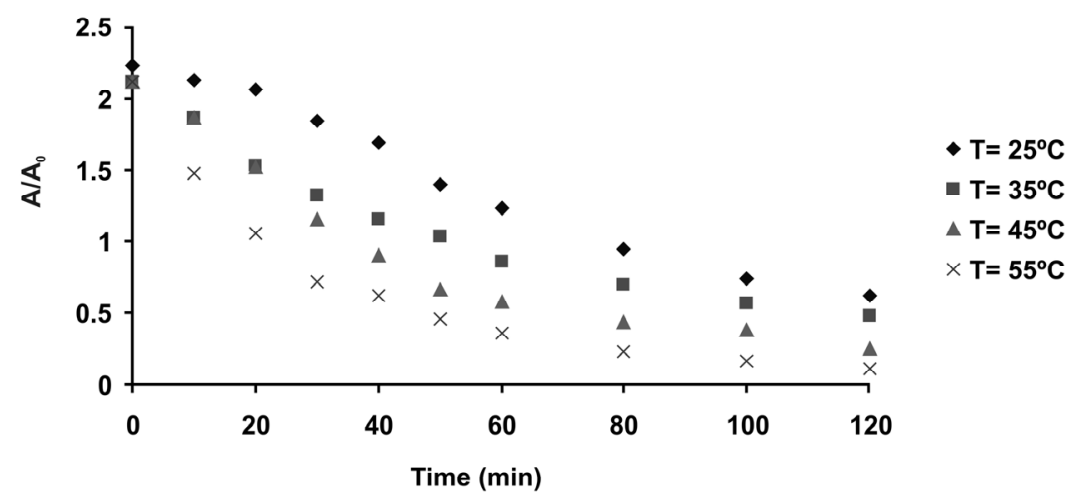

Figure 4: Effect of temperature on the colour removal of the dye solution by heterogeneous Fenton oxidation. $\mathrm{A}=$ final absorbance, $\mathrm{A}_{0}=$ initial absorbance. Initial conditions: $\left[\mathrm{H}_{2} \mathrm{O}_{2}\right]=200 \mathrm{mg} / \mathrm{L}$; [dye] $=100 \mathrm{mg} / \mathrm{L}$, [hematite] $=10 \mathrm{~g} / \mathrm{L}, \mathrm{pH}=2.5$.

Table 3: Reaction rates and apparent activation energy for the hematite $/ \mathrm{H}_{2} \mathrm{O}_{2}$ system

\begin{tabular}{|c|c|c|c|c|}
\hline $\begin{array}{c}\text { Experimental } \\
\text { Condition }\end{array}$ & $\begin{array}{c}\mathbf{T} \\
\left({ }^{\circ} \mathbf{C}\right)\end{array}$ & $\begin{array}{c}\mathbf{R}_{\mathbf{0}} \\
\left(\mathbf{m i n}^{-\mathbf{1}}\right)\end{array}$ & $\begin{array}{c}\mathbf{R}^{\mathbf{2}} \\
\text { Coefficients }\end{array}$ & $\begin{array}{c}\text { Activation Energy } \\
(\mathbf{k c a l} / \mathbf{m o l})\end{array}$ \\
\hline$\left[\mathrm{H}_{2} \mathrm{O}_{2}\right]_{0}=200 \mathrm{mg} / \mathrm{L}$ & 25 & 0.0104 & 0.9814 & \\
{$[\mathrm{Hematite}]_{0} 10 \mathrm{~g} / \mathrm{L}$} & 35 & 0.0245 & 0.9054 & 10.6 \\
$\mathrm{pH}=25$ & 45 & 0.0248 & 0.8461 & \\
& 55 & 0.0642 & 0.7509 & \\
\hline
\end{tabular}

\section{Mechanistic Considerations}

The following thermodynamic evaluations and further experiments were made in an attempt to further elucidate the reaction mechanism. Such considerations are made initially in the next sections, for simplified conditions, taking into consideration the interactions between $\mathrm{Fe}_{2} \mathrm{O}_{3}$, aqueous $\mathrm{Fe}$ species, and $\mathrm{H}_{2} \mathrm{O}_{2}$ in water only, without the dye; subsequently, the presence of the dye is considered.

\section{Calculations of $\mathrm{Fe}(\mathrm{II})$ and $\mathrm{Fe}(\mathrm{III})$ Speciation in Aqueous Solutions in Contact with $\mathrm{Fe}_{2} \mathrm{O}_{3}$ (in the Absence of the Dye)}

The $\mathrm{e}_{\mathrm{H}}-\mathrm{pH}$ diagram for $\mathrm{Fe}$ species (for [Fe] total $=1 \times 10^{-6} \mathrm{~mol} / \mathrm{L}$ ) in water shown in Figure 5 was calculated in the present work using Outotek's HSC 7.0 programme. It shows the known aqueous and most stable solid iron species that may be present under the considered reaction conditions in the range pH 2.5 to 5.5. It can be seen that the solid $\mathrm{Fe}_{2} \mathrm{O}_{3}$ species is predominant over the aqueous $\mathrm{Fe}$ (III) species $\left(\mathrm{Fe}^{3+} ; \mathrm{FeOH}^{2+}\right.$; and $\left.\mathrm{HFeO}_{2}\right)$ in the range of $\mathrm{pH}>2.0$ and that this same solid species can be converted to aqueous $\mathrm{Fe}^{2+}$ by a reduction in the operating $\mathrm{pH}$ range of the present study. The diagram also shows that, although $\mathrm{Fe}_{2} \mathrm{O}_{3}$ has a very low aqueous solubility across the considered range of $\mathrm{pH} 2.5$ to 5.5, aqueous iron species can exist in equilibrium with the mineral suspension, these being: $\mathrm{Fe}^{3+}(\mathrm{pH}<2.1)$; $\mathrm{FeOH}^{2+}(2.1<\mathrm{pH}<3.2)$; $\mathrm{HFeO}_{2}(\mathrm{pH}>3.2)$; and $\mathrm{Fe}^{2+}$ (over the whole $\mathrm{pH}$ range considered).

Calculation of the Possibility of the $\mathrm{Fe}_{2} \mathrm{O}_{3}$ Surface Redox Reaction with $\mathrm{H}_{2} \mathrm{O}_{2}$ Leading to Mineral Dissolution and Decomposition of $\mathrm{H}_{2} \mathrm{O}_{2}$ to $\mathrm{O}_{2}$

Lin and Gurol (1998) and Kwan and Voelker (2003) have considered that the mechanism of the heterogeneous Fenton process involves a complex series of reactions on the surface of the catalyst producing $\mathrm{HO}^{\circ}$ and $\mathrm{HO}_{2}{ }^{\circ}$ radicals (reactions $1-4$ ).

$$
\begin{aligned}
& \mathrm{Fe}^{3+}+\mathrm{H}_{2} \mathrm{O}_{2} \rightarrow \mathrm{Fe}^{2+}+\mathrm{HO}_{2} \cdot+\mathrm{H}^{+} \\
& \mathrm{Fe}^{2+}+\mathrm{H}_{2} \mathrm{O}_{2} \rightarrow \mathrm{Fe}^{3+}+{ }^{-} \mathrm{OH}+\mathrm{HO}^{\bullet} \\
& \mathrm{HO}_{2} \bullet \leftrightarrow \mathrm{H}^{+}+\mathrm{O}_{2}{ }^{\bullet-} \\
& \mathrm{Fe}^{3+}+\mathrm{HO}_{2} \rightarrow \mathrm{Fe}^{2+}+\mathrm{H}^{+}+\mathrm{O}_{2}
\end{aligned}
$$




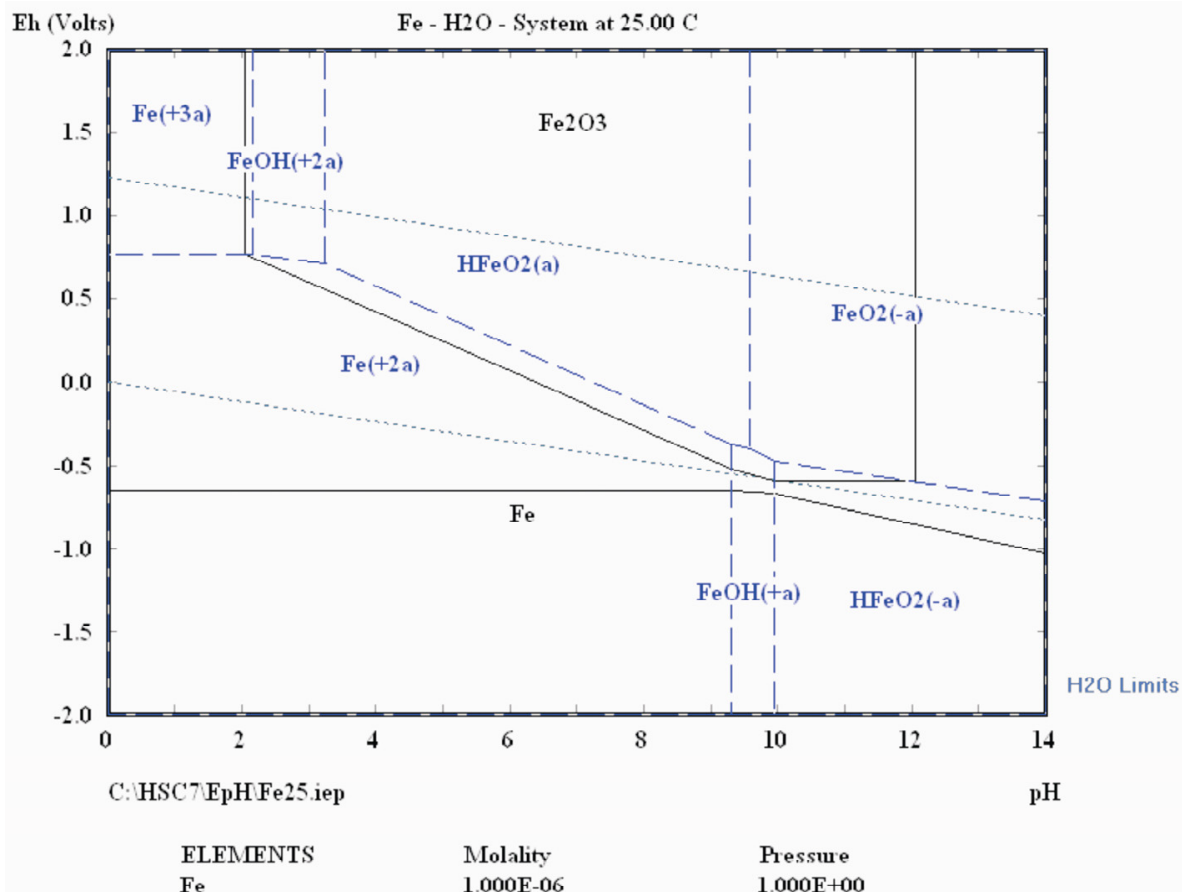

Figure 5: $\mathrm{E}_{\mathrm{H}}-\mathrm{pH}$ diagram of $\mathrm{Fe}$ species in water with total $[\mathrm{Fe}]=1.0 \times 10^{-6} \mathrm{~mol} / \mathrm{L}-$ dotted lines show the boundaries of aqueous species only.

Pham et al. (2009) have also suggested other rather similar mechanisms - including adaptations to heterogeneous Fenton reaction condition steps based on the original Haber-Weiss mechanism. In those studies, the bottom line is: aqueous $\mathrm{H}_{2} \mathrm{O}_{2}$ on the surface of hematite decomposes to $\mathrm{H}_{2} \mathrm{O}+\mathrm{O}_{2}$. This may either initiate via a true surface catalytic path of generation of intermediate $\mathrm{HO}^{\bullet}$ or $\mathrm{HO}_{2}{ }^{\circ}$ free radicals or, as we will discuss below, a noncatalytic, non-radical redox route by which solid $\mathrm{Fe}_{2} \mathrm{O}_{3}$ may actually release $\mathrm{Fe}$ ions to the solution via a reductive step that leads to aqueous $\mathrm{Fe}^{2+}\left(+\mathrm{O}_{2}\right)$. The released aqueous $\mathrm{Fe}^{2+}$, together with remaining $\mathrm{H}_{2} \mathrm{O}_{2}$ in the solution, could then fuel a continuing conventional homogeneous Fenton reaction step.

The $\mathrm{Fe}_{2} \mathrm{O}_{3}$ dissolution reactions below will occur to a certain extent limited by $\mathrm{pH}$ and reach equilibrium with the specific predominant dissolved $\mathrm{Fe}$ species indicated for each $\mathrm{pH}$ range (equilibrium solubility constants calculated using Outotek's HSC 7.0):

$$
\begin{aligned}
& \text { (at } \mathrm{pH}>3.2) \\
& \mathrm{Fe}_{2} \mathrm{O}_{3(\mathrm{~s})}+\mathrm{H}_{2} \mathrm{O} \rightarrow 2 \mathrm{HFeO}_{2(\text { aq })} \\
& \mathrm{K}=1.1 \times 10^{-17}
\end{aligned}
$$

$$
\begin{aligned}
& (\text { at } 2.1<\mathrm{pH}<3.2) \\
& \mathrm{Fe}_{2} \mathrm{O}_{3(\mathrm{~s})}+4 \mathrm{H}^{+}{ }_{(\text {aq })} \rightarrow 2 \mathrm{FeOH}^{2+}{ }_{(\mathrm{aq})}+\mathrm{H}_{2} \mathrm{O} \\
& \mathrm{K}=8.7 \times 10^{-5} \\
& (\text { at } \mathrm{pH}<2.1) \\
& \mathrm{Fe}_{2} \mathrm{O}_{3(\mathrm{~s})}+6 \mathrm{H}^{+}{ }_{(\text {aq })} \rightarrow 2 \mathrm{Fe}^{3+}{ }_{(\mathrm{aq})}+3 \mathrm{H}_{2} \mathrm{O} \\
& \mathrm{K}=1.9
\end{aligned}
$$

The magnitudes of the constants indicate that the more acidic dissolution of $\mathrm{Fe}_{2} \mathrm{O}_{3}$ to $\mathrm{Fe}^{3+}$ is more favourable than less acidic dissolution to $\mathrm{FeOH}^{2+}$ or to neutral $\mathrm{HFeO}_{2}$, but in each of the above considered $\mathrm{pH}$ ranges, at least one of the three species will be dissolved, even if only to a limited extent, as is the case of $\mathrm{HFeO}_{2}$ and $\mathrm{FeOH}^{2+}$.

Once the aqueous $\mathrm{Fe}$ species are released into solution, these can induce the redox decomposition of $\mathrm{H}_{2} \mathrm{O}_{2}$ through the following Equations (8-10):

$$
\begin{aligned}
& \mathrm{HFeO}_{2(\mathrm{aq})}+3 / 2 \mathrm{H}_{2} \mathrm{O}_{2}+2 \mathrm{H}^{+} \rightarrow \\
& \mathrm{Fe}^{2+}{ }_{(\mathrm{aq})}+3 \mathrm{H}_{2} \mathrm{O}+\mathrm{O}_{2} \\
& \mathrm{~K}=1.3 \times 10^{25}
\end{aligned}
$$




$$
\begin{aligned}
& \mathrm{FeOH}^{2+}{ }_{\text {(aq) }}+3 / 2 \mathrm{H}_{2} \mathrm{O}_{2(\text { aq })} \rightarrow \\
& \mathrm{Fe}^{2+}{ }_{\text {(aq) }}+2 \mathrm{H}_{2} \mathrm{O}+\mathrm{O}_{2} \\
& \mathrm{~K}=4.6 \times 10^{18} \\
& \mathrm{Fe}^{3+}{ }_{\text {(aq) }}+1 / 2 \mathrm{H}_{2} \mathrm{O}_{2(\text { aq) }}+\mathrm{OH}^{-}{ }_{(\mathrm{aq})} \rightarrow \\
& \mathrm{Fe}^{2+}{ }_{\text {(aq) }}+1 / 2 \mathrm{O}_{2(\mathrm{aq})}+\mathrm{H}_{2} \mathrm{O} \\
& \mathrm{K}=4.9 \times 10^{27}
\end{aligned}
$$

The combination of the above reactions in pairs (5 with $8 ; 6$ with 9; and 7 with 10 ) for each $\mathrm{pH}$ range results in the same overall reaction:

$$
\begin{aligned}
& \mathrm{Fe}_{2} \mathrm{O}_{3(\mathrm{~s})}+\mathrm{H}_{2} \mathrm{O}_{2(\mathrm{aq})}+4 \mathrm{H}^{+}{ }_{(\mathrm{aq})} \rightarrow \\
& 2 \mathrm{Fe}^{2+}{ }_{(\mathrm{aq})}+3 \mathrm{H}_{2} \mathrm{O}+\mathrm{O}_{2} \\
& \mathrm{~K}=7.1 \times 10^{2}
\end{aligned}
$$

This analysis shows that it is thermodynamically feasible that $\mathrm{Fe}_{2} \mathrm{O}_{3}$ in contact with $\mathrm{H}_{2} \mathrm{O}_{2}$ in acidic solutions will lead to $\mathrm{Fe}^{2+}$ ions in solution, which in turn will initiate the homogeneous Fenton reaction step with the remaining $\mathrm{H}_{2} \mathrm{O}_{2}$. This is depicted by the equilibrium constant expression for reaction (11) rearranged below:

$$
\left[\mathrm{Fe}^{2+}\right]=710\left[\mathrm{H}^{+}\right]^{4}\left[\mathrm{H}_{2} \mathrm{O}_{2}\right] /\left[\mathrm{O}_{2}\right]
$$

This expression shows how strongly dependent on $\mathrm{pH}$ the critical step of $\mathrm{Fe}^{2+}{ }_{\text {(aq) }}$ generation and propagation of the homogeneous Fenton reaction is in the overall dye degradation reaction. This is supported by our results presented here and by those of previous investigators.

Thus, at this point of the discussion, it may be considered that the heterogeneous Fenton process is likely to start on the hematite surface by either: (a) catalytic decomposition of adsorbed $\mathrm{H}_{2} \mathrm{O}_{2}$ leading to adsorbed $\mathrm{HO}^{-}$and $\mathrm{HO}_{2}{ }^{\circ}$, which, either still on the surface or just after desorption, will attack nearby (adsorbed or not) dye molecules, as proposed by Lin and Gurol (1998) - reactions (1) to (4); or (b) as proposed in the present work: with reduction and release of surface $\mathrm{Fe}^{3+}$ as $\mathrm{Fe}^{2+}$ into the solution, in which $\mathrm{H}_{2} \mathrm{O}_{2}$ plays the role of reductant. Once in solution, $\mathrm{Fe}^{2+}$ will react with the remaining $\mathrm{H}_{2} \mathrm{O}_{2}$, as in a conventional homogeneous Fenton reaction, inducing degradation of the dye molecules. Although not specifically demonstrated in previous works, this hypothesis supports the findings of previous authors (Chou and Huang, 1999; Teel et al., 2001; Lu et al., 2002) who suggested that the mechanism of the heterogeneous Fenton reaction merely starts on the surface and continues mainly in the bulk of the aqueous solution as a homogeneous Fenton reaction.

\section{Decomposition of $\mathrm{H}_{2} \mathrm{O}_{2}$ Induced by the Hematite Surface}

Figure 6 shows the decomposition of $0.5 \mathrm{~g} / \mathrm{L}$ $\mathrm{H}_{2} \mathrm{O}_{2}$ (solution without added dye), induced by 10 $\mathrm{g} / \mathrm{L}$ of hematite powder in the absence of the dye. It can be seen that the decomposition is appreciably faster at $\mathrm{pH} 2.5$ as compared to that at $\mathrm{pH}$ 5.5. Whatever the decomposition mechanism may be, i.e., either true surface Fenton-like or reductive, the experiment shows a slow rate of $\mathrm{H}_{2} \mathrm{O}_{2}$ disappearance at $\mathrm{pH} 5.5$, which is in agreement with the observed effect of $\mathrm{pH}$ seen in the dye degradation runs.

At $\mathrm{pH}$ 5.5, the $\mathrm{H}_{2} \mathrm{O}_{2}$ decomposition reaction is fairly slow and the $\mathrm{pH}$ remains basically stable during the reaction. This may be due to the occurrence of sequential redox reactions that end up converting $\mathrm{Fe}_{2} \mathrm{O}_{3}$ to the sparingly soluble neutral complex $\mathrm{HFeO}_{2}$ (aq) without overall variation in acidity:

$$
\begin{aligned}
& 2 \mathrm{Fe}^{2+}+\mathrm{H}_{2} \mathrm{O}_{2}+2 \mathrm{H}_{2} \mathrm{O} \rightarrow 2 \mathrm{HFeO}_{2(\mathrm{aq})}+4 \mathrm{H}^{+} \\
& \mathrm{K}=2.1 \times 10^{16}
\end{aligned}
$$

which combines with Eq. (11) to give:

$$
\begin{aligned}
& \mathrm{Fe}_{2} \mathrm{O}_{3(\mathrm{~s})}+2 \mathrm{H}_{2} \mathrm{O}_{2(\mathrm{aq})} \rightarrow 2 \mathrm{HFeO}_{2(\mathrm{aq})}+\mathrm{H}_{2} \mathrm{O}+\mathrm{O}_{2} \\
& \mathrm{~K}=1.6 \times 10^{19}
\end{aligned}
$$

However, at $\mathrm{pH} 2.5$, the analogous reaction path can lead to the conversion of $\mathrm{Fe}_{2} \mathrm{O}_{3}$ into the more soluble $\mathrm{FeOH}^{2+}{ }_{(\mathrm{aq})}$, according to the following reaction:

$$
\begin{aligned}
& 2 \mathrm{Fe}^{2+}+\mathrm{H}_{2} \mathrm{O}_{2} \rightarrow 2 \mathrm{FeOH}^{2+}{ }_{\text {(aq) }} \\
& \mathrm{K}=1.8 \times 10^{29}
\end{aligned}
$$

which combines with Eq. (11) to give:

$$
\begin{aligned}
& \mathrm{Fe}_{2} \mathrm{O}_{3(\mathrm{~s})}+2 \mathrm{H}_{2} \mathrm{O}_{2(\mathrm{aq})}+4 \mathrm{H}^{+} \rightarrow \\
& 2 \mathrm{FeOH}^{2+}{ }_{(\mathrm{aq})}+3 \mathrm{H}_{2} \mathrm{O}+\mathrm{O}_{2} \\
& \mathrm{~K}=1.8 \times 10^{29}
\end{aligned}
$$


Under this condition of initial $\mathrm{pH}=2.5$, as the reaction proceeds, the $\mathrm{pH}$ should increase; this is also supported by the results of the decomposition runs in Figure 6.

Thus, it can be concluded that the hypothesis of a non-radical path for the decomposition of $\mathrm{H}_{2} \mathrm{O}_{2}$ by $\mathrm{Fe}_{2} \mathrm{O}_{3}$, proceeding via reductive $\mathrm{Fe}^{2+}$ dissolution leading to $\mathrm{O}_{2}$ generation, followed by oxidation to $\mathrm{Fe}(\mathrm{III})\left(\right.$ as $\mathrm{HFeO}_{2}$ at $\mathrm{pH} 5.5$ or $\mathrm{FeOH}^{2+}$ at $\mathrm{pH} 2.5$ ) by peroxide, may be a possible inducer of a conventional homogeneous Fenton degradation step of the dye.

In addition to this conclusion, one should also

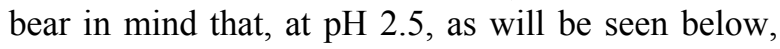
some dissolution of iron from the hematite surface occurs - and, because the aqueous couple $\mathrm{Fe}^{2+} / \mathrm{Fe}^{3+}$ is a known catalyst for $\mathrm{H}_{2} \mathrm{O}_{2}$ degradation, like other aqueous transition metal species, this will also contribute to $\mathrm{H}_{2} \mathrm{O}_{2}$ decomposition in the dye degradation process.

The solubilisation rates of iron as $\mathrm{Fe}^{2+}$ and $\mathrm{Fe}^{3+}$ were also measured. In runs conducted at $\mathrm{pH}=5.5$, after 120 minutes, only a very limited extent of iron dissolution was detected - a maximum of $0.21 \mathrm{mg} / \mathrm{L}$. At $\mathrm{pH}=2.5$, though, a higher extent of iron dissolution (up to $0.68 \mathrm{mg} / \mathrm{L}$ ) was observed in the same period of time. The evolution of iron dissolution with time is shown in Figure 7. It is seen that the presence of $\mathrm{H}_{2} \mathrm{O}_{2}$ causes faster iron dissolution from the hematite surface.

The acidic medium condition $(\mathrm{pH}=2.5)$ resulted in some dissolution of the mineral catalyst, leading to total dissolved iron levels reaching $0.68 \mathrm{mg} / \mathrm{L}$ and $0.63 \mathrm{mg} / \mathrm{L}$ for runs with and without hydrogen peroxide, respectively. Because the concentration levels of leached iron were very low, there will be no need for control of the amount of iron in solution.

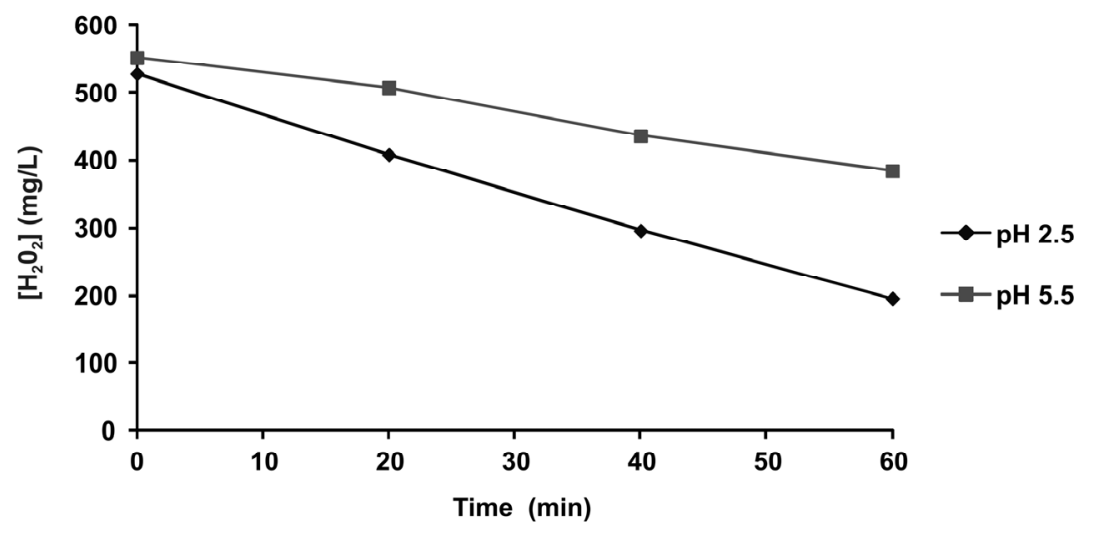

Figure 6: Disappearance of initial $0.5 \mathrm{mg} / \mathrm{L} \mathrm{H}_{2} \mathrm{O}_{2}$ in contact with suspended hematite powder at [hematite] $=20 \mathrm{~g} / \mathrm{L}, \mathrm{pH} 2.5$ and $\mathrm{pH} 5.5$, at $25^{\circ} \mathrm{C}$.

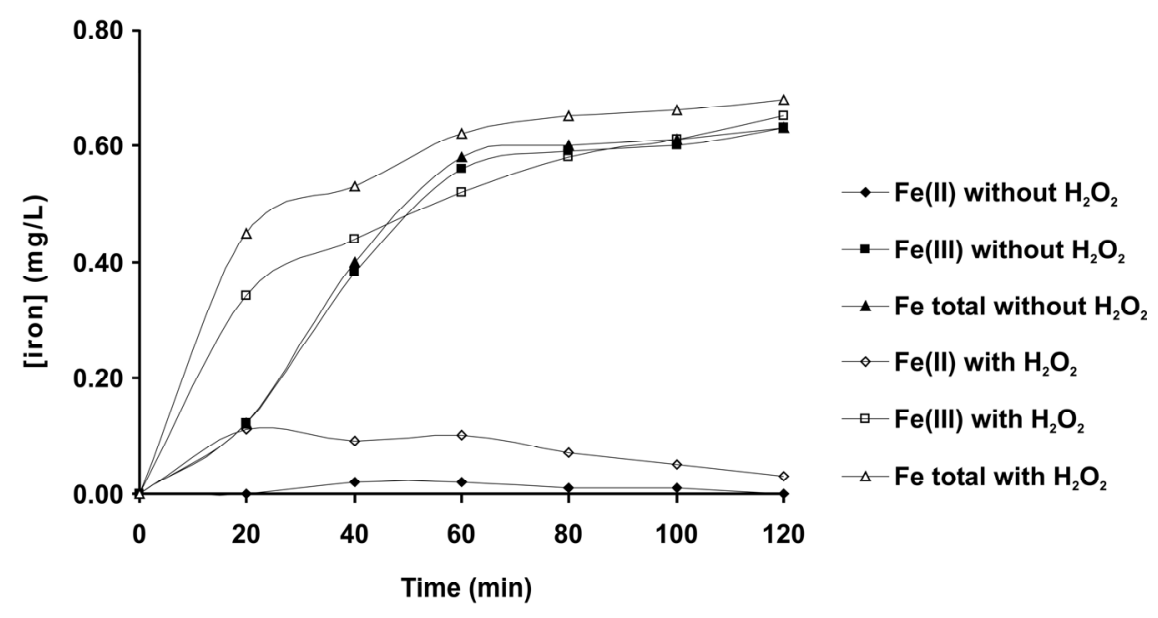

Figure 7: Effect of hydrogen peroxide on the dissolution of hematite. Initial conditions: $[$ hematite $]=20 \mathrm{~g} / \mathrm{L}, \mathrm{pH}=2.5, \mathrm{~T}=25^{\circ} \mathrm{C}$. 
A point to be noted is that, in the trials carried out at $\mathrm{pH}=2.5$ without hydrogen peroxide, most of the iron ions present in solution were ferric ions $\left(\mathrm{Fe}^{3+}>\right.$ 99\%) and no significant amounts of ferrous ions were detected. However, in the trials carried out with $\mathrm{H}_{2} \mathrm{O}_{2}$, ferrous ions were detected in solution, reaching a maximum of $0.11 \mathrm{mg} / \mathrm{L}$ at 20 minutes of reaction, and decreasing to $0.03 \mathrm{mg} / \mathrm{L}$ after 120 minutes. Since these ions were not added to the solution and the mineral had only $\mathrm{Fe}^{3+}$ ions in its structure, the ferrous ions were produced by the reaction between $\mathrm{Fe}^{3+}$ ions on the hematite surface and $\mathrm{H}_{2} \mathrm{O}_{2}$ (reaction 11). This confirms our thermodynamic analysis of the generation of $\mathrm{Fe}^{2+}$ ions in solution. This is also in reasonable agreement with the results reported by Lin and $\mathrm{Lu}$ (2006), who observed that, after 90 minutes of contact between iron oxides and solutions containing hydrogen peroxide, more than $90 \%$ of the ions present in the solution were ferrous ions; after that period, the concentration of $\mathrm{Fe}^{2+}$ ions decreased to a negligible value.

\section{Further Experiments in the Presence of the Dye}

In an attempt to correlate aqueous iron dissolution (homogeneous Fenton activity) with discolouration during the heterogeneous Fenton reaction at $\mathrm{pH} 2.5$, the experiment shown in Figure 8 was performed (evolution of iron $\mathrm{Fe}^{2+}$ and $\mathrm{Fe}^{3+}$ in solution and colour removal).

Although it was seen that in the presence of the dye, a non-negligible amount of dissolved iron (which could function as a homogeneous Fenton catalyst) was detected only after 20 minutes of reaction. In this same period of time, about $50 \%$ of the colour had already been removed. Although the presence of the dye seems to interfere with the $\mathrm{F}_{2} \mathrm{O}_{3}$ /aqueous interface, the dye molecules, being much larger in size than single iron ions on the hematite surface, are somehow able to inhibit dissolution of Fe from the mineral. Thus, at the beginning of the reaction the colour removal occurs predominantly as result of a heterogeneous reaction between hydrogen peroxide and the hematite surface, which is sufficiently active to initiate a process of generation of free radicals that attack the nearby dye molecules.

\section{Heterogeneous and Homogeneous Generation of Free Radicals}

In order to evaluate the contribution of the homogeneous reaction during the overall heterogeneous Fenton process, a further trial was carried out by using as catalyst only the aqueous iron ions produced by hematite dissolution at $\mathrm{pH}=2.5$ in the absence of $\mathrm{Fe}_{2} \mathrm{O}_{3}$. The experiment was carried out after $120 \mathrm{~min}$ of contact between the suspended hematite powder $(20 \mathrm{~g} / \mathrm{L})$ and the dye solution $(100 \mathrm{mg} / \mathrm{L})$ at $\mathrm{pH}=2.5$, without addition of $\mathrm{H}_{2} \mathrm{O}_{2}$. The solution was then filtered to separate the solid catalyst. The filtrate was analyzed for iron content and, after adding $\mathrm{H}_{2} \mathrm{O}_{2}(800 \mathrm{mg} / \mathrm{L})$, discolouration was monitored for an additional 120 minutes of reaction time.

Figure 9 shows the comparison between the discolouration of the dye solution by the heterogeneous Fenton system with hematite and the homogeneous Fenton process performed with the filtered solution obtained after contact with the hematite powder suspension for $120 \mathrm{~min}$ at $\mathrm{pH}=2.5$. It noted that, after this contact period, the total concentration of dissolved iron in the solution reached $0.49 \mathrm{mg} / \mathrm{L}$ and, according to Figure 7, most of which should be in the form of $\mathrm{Fe}^{3+}$.

This experiment showed that the rate of colour removed was significantly higher in the presence of hematite - especially in the first 30 minutes of reaction, where about $70 \%$ of the degradation occurs, reaching approximately $99 \%$ after $120 \mathrm{~min}$ of reaction. In the comparative homogeneous process done with leached aqueous iron only, the discolouration did not exceed $63 \%$ in the same $120 \mathrm{~min}$ period.

An analogous comparative experiment reported recently by Liang et al. (2010) for degradation of an azo dye by $\mathrm{H}_{2} \mathrm{O}_{2}$ activated by a magnetite catalyst suspension also led to similar conclusions. When the discoloration reaction was conducted at an initial $\mathrm{pH} 3$, the discoloration of Acid Orange II by the homogeneous Fenton reaction was below $10 \%$ after $180 \mathrm{~min}$. Most of the decomposition of the dye catalyzed by magnetite was due to a heterogeneous rather than a homogeneous Fenton reaction.

Thus, the above observations support the conclusion of the present study that the dye discolouration by means of the $\mathrm{Fe}_{2} \mathrm{O}_{3} / \mathrm{H}_{2} \mathrm{O}_{2}$ system occurs predominantly as a result of the reaction between hydrogen peroxide and iron present on the hematite surface, which generates radicals in conditions adequate for attacking adsorbed dye molecules. In addition, the homogeneous Fentontype reaction due to the reductive release of ferric ions from the mineral into the solution $\left(\mathrm{as} \mathrm{Fe}^{2+}\right)$ also plays a continuing role in the overall reaction, which should show an autocatalytic kinetic behaviour.

In fact, the kinetic curves shown in Figure 10 show the autocatalytic behaviour derived from a combination of a slow initial heterogeneous step of $\mathrm{HO}^{\bullet}$ or $\mathrm{HO}_{2}{ }^{-}$formation that begins on the hematite surface (and appears as a typical induction period), followed by a dissolution step that reduces and transforms surface $\mathrm{Fe}^{3+}$ to aqueous $\mathrm{Fe}^{2+}$ that can react with the remaining $\mathrm{H}_{2} \mathrm{O}_{2}$ to generate more $\mathrm{HO}^{\bullet}$ radicals and accelerate the overall reaction. 


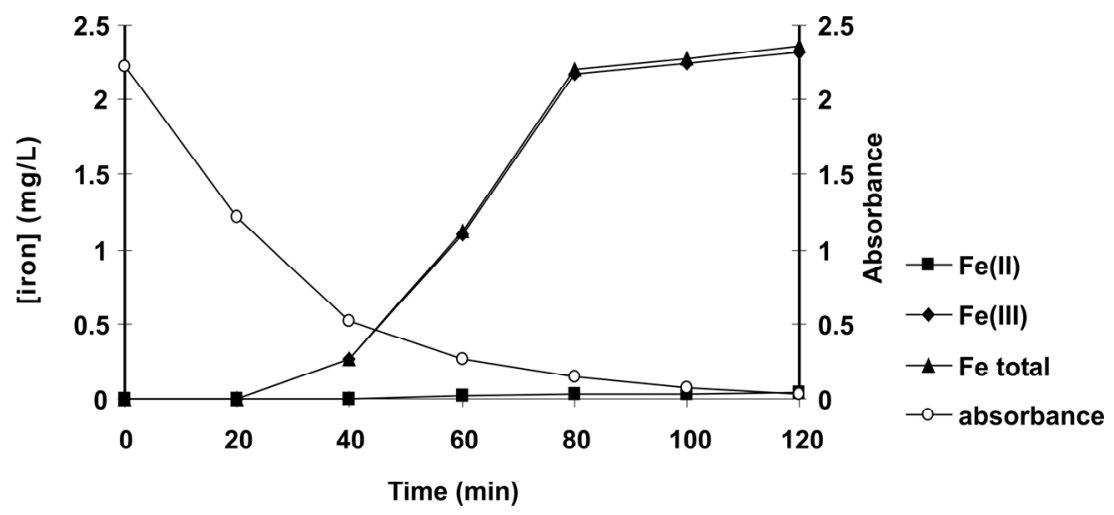

Figure 8: Dissolution of iron and absorbance of reactive dye solution in the heterogeneous Fenton reaction. Initial conditions: [dye] $=100 \mathrm{mg} / \mathrm{L}$; $[$ hematite $]=20 \mathrm{~g} / \mathrm{L} ;\left[\mathrm{H}_{2} \mathrm{O}_{2}\right]=800 \mathrm{mg} / \mathrm{L} ; \mathrm{pH}=2.5$.

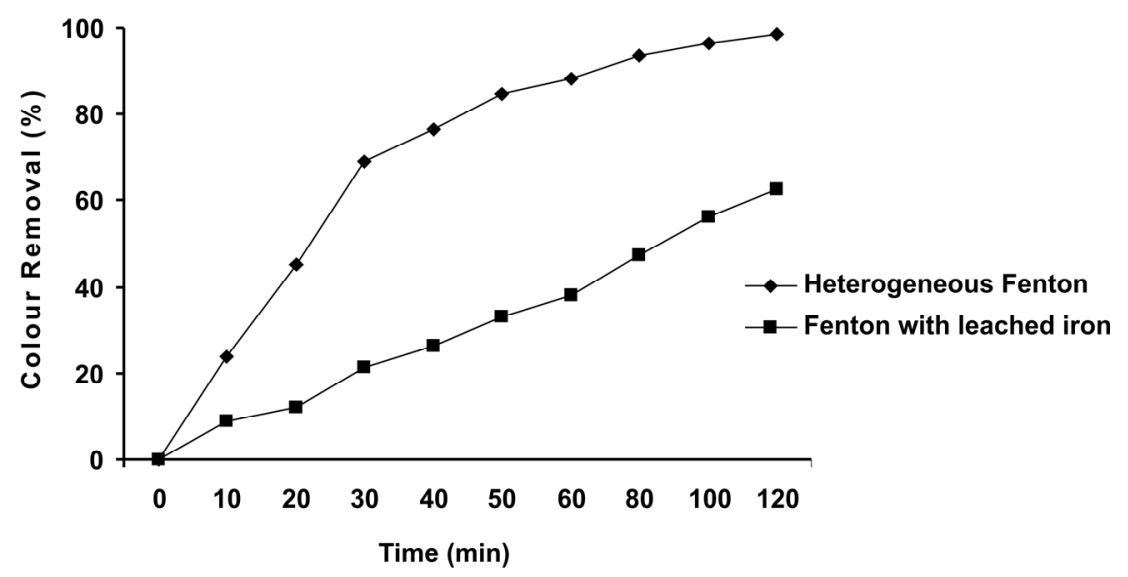

Figure 9: Discolouration of reactive dye solutions by the heterogeneous Fenton process with [hematite] $=20 \mathrm{~g} / \mathrm{L}$ and the homogeneous Fenton process with leached iron $([\mathrm{Fe}]=0.49 \mathrm{mg} / \mathrm{L})$ obtained from leaching hematite for 2 hours under same conditions. Initial conditions: $[$ dye $]=100 \mathrm{mg} / \mathrm{L} ;\left[\mathrm{H}_{2} \mathrm{O}_{2}\right]=800 \mathrm{mg} / \mathrm{L} ; \mathrm{pH}=2.5$.

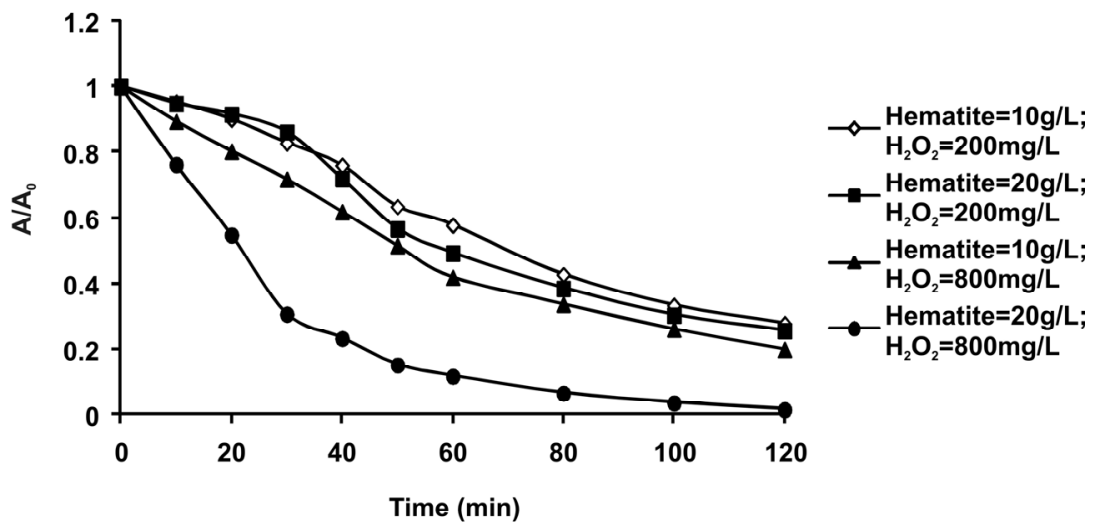

Figure 10: Additional dye degradation runs showing autocatalytic kinetic behavior. Initial conditions: $[$ dye $]=100 \mathrm{mg} / \mathrm{L} ;\left[\mathrm{H}_{2} \mathrm{O}_{2}\right]=200-800 \mathrm{mg} / \mathrm{L}$; [hematite] $=10-20$ $\mathrm{g} / \mathrm{L} ; \mathrm{pH}=2.5$. 


\section{CONCLUSIONS}

1. The heterogeneous Fenton process using the mineral hematite in powder form was effective in removing the colour of $100 \mathrm{mg} / \mathrm{L}$ Drimarene Red X$6 \mathrm{BN}$ azo-dye solutions.

2. The three process variables investigated: $\mathrm{H}_{2} \mathrm{O}_{2}$ dose $(100-800 \mathrm{mg} / \mathrm{L})$; hematite powder concentration $(1-20 \mathrm{~g} / \mathrm{L})$, and $\mathrm{pH}(2.5-5.5)$, showed strong effects on the rate and efficiency. An increased hematite concentration and hydrogen peroxide dose both contributed to an increase in the rate and efficiency of the dye colour removal, due to the greater surface area of the catalyst and supply of free radicals from $\mathrm{H}_{2} \mathrm{O}_{2}$ decomposition. A strongly acidic medium $(\mathrm{pH}=2.5)$ was found to be much more favourable than a near neutral $\mathrm{pH} 5.5$ for the generation of free radicals that are capable of attacking the dye molecules. The apparent activation energy of the reaction was calculated to be $10.6 \mathrm{kcal} / \mathrm{mol}$, indicating a mechanism controlled by chemical reaction.

3. A thermodynamic evaluation of possible reactions, confirmed by kinetic runs, indicated that the action of hydrogen peroxide on the hematite surface can provide a significant contribution to the reaction kinetics by promoting the formation of ferrous ions in the course of the reaction via a Fenton-like heterogeneous step, according to the following reaction:

$$
\begin{aligned}
& \mathrm{Fe}_{2} \mathrm{O}_{3(\mathrm{~s})}+4 \mathrm{H}_{(\text {aq })}^{+}+\mathrm{H}_{2} \mathrm{O}_{2(\text { aq })} \rightarrow \\
& 2 \mathrm{Fe}_{(\text {ads, aq })}^{2+}+3 \mathrm{H}_{2} \mathrm{O}+\mathrm{O}_{2}
\end{aligned}
$$

4. By analogy to a conventional homogeneous Fenton process, surface $\mathrm{Fe}^{3+}$ ions in the presence of adsorbed $\mathrm{H}^{+}$may be reduced by adsorbed $\mathrm{H}_{2} \mathrm{O}_{2}$ in what would be a (heterogeneous) Fenton-like reaction, inducing $\mathrm{H}_{2} \mathrm{O}_{2}$ decomposition to adsorbed $\mathrm{HO}_{2}{ }^{\bullet}$ and leaving surface iron ions as $\mathrm{Fe}^{2+}$ that can provoke further $\mathrm{H}_{2} \mathrm{O}_{2}$ decomposition leading to generation of $\mathrm{HO}^{\bullet}$ capable of attacking nearby dye molecules. In the course of the reaction, the surface $\mathrm{Fe}^{2+}$ ions end up dissolving because they have a much higher solubility than $\mathrm{Fe}^{3+}$. Dissolved $\mathrm{Fe}^{2+}$ ions then also propagate the conventional homogeneous Fenton mechanism with the remaining $\mathrm{H}_{2} \mathrm{O}_{2}$.

\section{ACKNOWLEDGEMENTS}

Acknowledgments to SENAI/CETIQT, CETEM and Peroxidos do Brasil Ltda. (Solvay Group). This work was supported by the Brazilian Higher Education Agency CAPES.

\section{REFERENCES}

APHA, AWWA, WPCF, Standard Methods for the Examination of Water and Wastewater, 21th Ed. (2005).

Arslan, A. I., Balcioglu, I. A., Bahnemann, D. W., Advanced chemical oxidation of reactive dyes in simulated dyehouse effluents by ferrioxalateFenton/UV-A and $\mathrm{TiO}_{2} / \mathrm{UV}-\mathrm{A}$ processes. Dyes and Pigments. 47, p. 207 (2000).

Chou, S., Huang, C., Application of a supported iron oxyhydroxide catalyst in oxidation of benzoic acid by hydrogen peroxide. Chemosphere, 38, p. 2719 (1999).

Dantas, T. L. P., Mendonça, V. P., José, H. J., Treatment of textile wastewater by heterogeneous Fenton process using a new composite $\mathrm{Fe}_{2} \mathrm{O}_{3}$ /carbon. Chemical Engineering Journal, 118, p. 77 (2006).

Georgiou, D., Medelis, P., Aivasidis, A., Gimouhopoulos, K., Degradation of azo reactive dyes by ultraviolet radiation in the presence of hydrogen peroxide. Dyes and Pigments, 52, p. 69 (2002).

Herrera, F., Lopez, A., Mascolo, G., Catalytic decomposition of the reactive dye uniblue $\mathrm{A}$ on hematite. Modeling of the reactive surface, Water Research, 35, p. 750 (2001).

Kang, S. F., Liao, C. H., Chen, M. C., Pre-oxidation and coagulation of textile wastewater by the Fenton process. Chemosphere, 46, p. 923 (2002).

Khan, M. D., Watts, R. J., Mineral-catalyzed peroxidation of tetrachloroethylene. Water, Air and Soil Pollution, 88, p. 247 (1996).

Kin, T. H., Park, C., Yang, J., Kim, S., Comparison of disperse and reactive dye removals by chemical coagulation and Fenton oxidation. J. Hazard. Mater. B112, p. 95 (2004).

Kong, S., Watts, R., Choi, J., Treatment of petroleum contaminated soils using iron mineral catalyzed hydrogen peroxide. Chemosphere, 37, p. 1473 (1998).

Kwan, W. P., Voelker, B. M. M., Rates of hydroxyl radical generation and organic compound oxidation in mineral-catalyzed Fenton-like systems. Environmental Science and Technology, 37, p. 1150 (2003).

Levenspiel, O., Chemical Reaction Engineering. Wiley, New York, (1962). 
Liang, X., Zhong, Y., Zhu, S., Zhu, J., Yuan, P., He, Y. and Zhang, J., The decolorization of Acid Orange II in non-homogeneous Fenton reaction catalyzed by natural vanadium-titanium magnetite. J. Hazard. Mater, 18, p. 112 (2010).

Lin, S. H., Lo, C. C., Fenton process for treatment of desizing wastewater. Water Research, 31, p. 2050 (1997).

Lin, S. S., Gurol, M. D., Catalytic decomposition of hydrogen peroxide on iron oxides: kinetics, mechanism and implication. Environmental Science and Technology, 32, p. 1417 (1998).

Lin, Y. T., Lu, M. C., Catalytic action of goethite in the oxidation of 2-chlorophenols with hydrogen peroxide. In: $4^{\circ}$ International Conferences on Oxidation Technologies for Water and Wastewater Treatment, CUTEC, 68 (2006).

Lu, M. C., Chen, J. N., Huang, H. H., Role of goethite in the oxidation of 2-chlorophenol with hydrogen peroxide. Chemosphere 46, p. 131 (2002).

Neamtu, M., Siminiceanu, I., Yediler, A., Kinetics of discoloration and mineralization of reactive azo dyes in aqueous solution by the $\mathrm{UV} / \mathrm{H}_{2} \mathrm{O}_{2}$ oxidation. Dyes and Pigments, 53, p. 93 (2002).

Oliveira, M. C., Nogueira, R. F. P., Neto, J. A. G., Sistema de injeção em fluxo espectrofotométrico para monitorar peróxido de hidrogênio residual em processo de fotodegradação por reação foto-
Fenton. Química Nova, 24, p. 188 (2001).

Pham, A. L., Lee, C, Doyle, F. M., Sedlak, D. L., A silica-supported iron oxide catalyst capable of activating hydrogen peroxide at neutral $\mathrm{pH}$ values. Environmental Science and Technology 43, p. 8930, (2009).

Plata, G. B. O., Alfano, O. M., Cassano, A. E., Decomposition of 2-chlorophenol employing goethite as Fenton catalyst. I. Proposal of a feasible, combined reaction scheme of heterogeneous and homogeneous reactions. Applied Catalysis B: Environmental, 95, p. 1 (2010).

Pignatello, J. J., Dark and photoassisted $\mathrm{Fe}^{3+}$ catalysed degradation of chlorophenoxy herbicides by hydrogen peroxide. Environmental Science and Technology, 26, p. 944 (1992).

Swaminathan, K., Sandhya, S., Carmalin Sophia, A., Pachhade, K., Subrahmanyam, Y. V., Decolorization and degradation of $\mathrm{H}$-acid and other dyes using ferrous-hydrogen peroxide system. Chemosphere, 50, p. 619 (2003).

Teel, A. L., Warberg, C. R., Atkinson, D. A., Comparison of mineral and soluble iron Fenton catalysts for the treatment of trichloroetilene, Water Research, 35, p. 977 (2001).

Valentine, R. L., Wang, H. C. A., Iron oxide surface catalyzed oxidation of quinoline by hydrogen peroxide. J. Environ. Eng. 24, p. 31 (1998). 